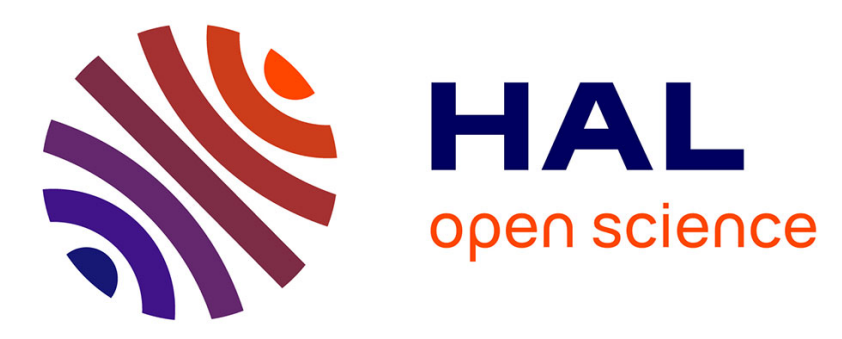

\title{
Tuning the CrIV/CrIII valence states in purple Cr-doped SnO2 nanopowders: the key role of CrIV centers and defects
}

Béatrice Serment, Manuel Gaudon, Olivier Toulemonde, Mathieu Duttine, Cyril Brochon, Alain Demourgues

\section{To cite this version:}

Béatrice Serment, Manuel Gaudon, Olivier Toulemonde, Mathieu Duttine, Cyril Brochon, et al.. Tuning the CrIV/CrIII valence states in purple Cr-doped $\mathrm{SnO} 2$ nanopowders: the key role of CrIV centers and defects. Inorganic Chemistry, 2019, 59 (1), pp.678-686. 10.1021/acs.inorgchem.9b02943 . hal-02490016

\section{HAL Id: hal-02490016 https://hal.science/hal-02490016}

Submitted on 22 Jun 2020

HAL is a multi-disciplinary open access archive for the deposit and dissemination of scientific research documents, whether they are published or not. The documents may come from teaching and research institutions in France or abroad, or from public or private research centers.
L'archive ouverte pluridisciplinaire HAL, est destinée au dépôt et à la diffusion de documents scientifiques de niveau recherche, publiés ou non, émanant des établissements d'enseignement et de recherche français ou étrangers, des laboratoires publics ou privés. 


\title{
Tuning the $\mathrm{Cr}^{\mathrm{IV}} / \mathrm{Cr}^{\mathrm{III}}$ Valence States in Purple $\mathrm{Cr}$-Doped $\mathrm{SnO}_{2}$ Nanopowders: The Key Role of $\mathrm{Cr}^{\mathrm{IV}}$ Centers and Defects
}

\author{
Béatrice Serment, ${ }^{\dagger \dagger}$ Manuel Gaudon, ${ }^{\dagger}$ Olivier Toulemonde, ${ }^{\dagger}$ Mathieu Duttine, ${ }^{\dagger}$ Cyril Brochon, ${ }^{\ddagger} \oplus$ \\ and Alain Demourgues* ${ }^{*}+\odot$
}

$\dagger$ CNRS, Université de Bordeaux, Bordeaux INP, ICMCB, UMR 5026, F-33600 Pessac, France

${ }^{\ddagger}$ CNRS, Université de Bordeaux, Bordeaux INP, LCPO, UMR 5629, F-33600 Pessac, France

ABSTRACT: A low content of chromium ( $\leq 5 \mathrm{~mol} \%)$ has been incorporated into a $\mathrm{SnO}_{2}$ cassiterite by a coprecipitation route in a basic medium, followed by an annealing step under an $\mathrm{O}_{2}$ flow at $\mathrm{T}=800{ }^{\circ} \mathrm{C}$ and $\mathrm{T}=1000{ }^{\circ} \mathrm{C}$. Accurate UV-vis and EPR spectroscopy investigations show the coexistence of isolated $\mathrm{Cr}^{4+}$ and $\mathrm{Cr}^{3+}$ ions as well as ferromagnetic $\mathrm{Cr}^{4+}-\mathrm{Cr}^{3+}$ and antiferromagnetic $\mathrm{Cr}^{3+}-\mathrm{Cr}^{3+}$ interactions. The strong purple hue is related to the isolated $\mathrm{Cr}^{4+}$ ions stabilized in a distorted octahedral site. This is thanks to the second-order Jahn-Teller (SOJT) effect with a crystal field splitting $10 \mathrm{Dq}$ value around $2.4 \mathrm{eV}$, whereas the $10 \mathrm{Dq}$ value is around $2 \mathrm{eV}$ for isotropic $\mathrm{Cr}^{3+}$ ions, partially substituted for $\mathrm{Sn}^{4+}$ ions in cassiterite. Just after the coprecipitation process, only $\mathrm{Cr}^{3+}$ species are stabilized in this rutile network with a poor crystallinity. The isolated $\mathrm{Cr}^{4+}$ content remains high after annealing at $800{ }^{\circ} \mathrm{C}$ for 2 days especially for the highest $\mathrm{Cr}$ rate $(2$ and $5 \mathrm{~mol}$ $\%)$, leading to a darker purple color, but unfortunately the $\mathrm{Cr}^{3+}$ content also

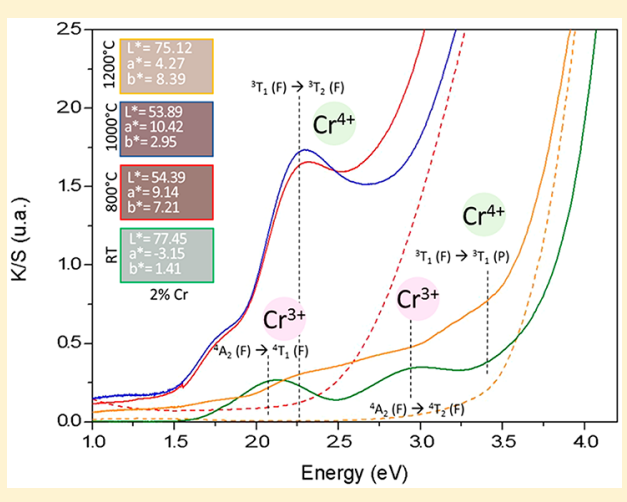
increases for a higher $\mathrm{Cr}$ concentration. A lighter purple hue can be reached after calcination at a higher temperature $(T=1000$ ${ }^{\circ} \mathrm{C}$ ) for a shorter time $(4 \mathrm{~h})$ but with a lower $\mathrm{Cr}$ content to avoid $\mathrm{Cr}$ clusters. This is due to stabilizing a high content of isolated $\mathrm{Cr}^{4+}$ species and limiting the $\mathrm{Cr}^{4+}-\mathrm{Cr}^{3+}$ ferromagnetic interactions, which are optimal for a $2 \% \mathrm{Cr}$ content and also cause the color to darken. The key roles of the $\mathrm{Cr}^{4+}$ rate and the $\mathrm{Cr}^{4+}-\mathrm{Cr}^{3+}$ clusters create local defects whose concentration strongly varies with a total $\mathrm{Cr}$ content, which have then been demonstrated to strongly influence the optical and magnetic properties.

\section{INTRODUCTION}

The control of the optical band gap (BG) and the nature and the rate of defects in a transparent oxide semiconductor and transition-metal-doped semiconducting materials are of high interest in optoelectronics, spintronic devices, sensors, transistors, electrode materials, and solar cells. ${ }^{1}$ Titanium $\left(\mathrm{TiO}_{2}\right)$, zinc $(\mathrm{ZnO})$, indium $\left(\mathrm{In}_{2} \mathrm{O}_{3}\right)$, and tin $\left(\mathrm{SnO}_{2}\right)$ binary oxides as n-type oxide semiconductors with a wide band gap have been largely explored as suitable candidates for this vast field of applications. Among these four oxides, stannic oxide $\mathrm{SnO}_{2}$ exhibits the highest direct band gap around $3.6 \mathrm{eV}$, with a refractive index around $n=2$ in the visible range. ${ }^{2}$ The synthesis route followed by annealing at high temperatures and the average crystallite size of tin dioxide that adopts a rutiletype structure strongly affects the optical band gap. ${ }^{1,2}$ The occurrence of defects within the crystals, including interstitial tin atoms, oxygen vacancies, or hydroxyl groups, contributes to create various impurity energy levels. Stannic oxides doped with low rates $(<5$ at. \%) of $3 \mathrm{~d}$ transition metals such as $\mathrm{Cr}^{3+}\left(3 \mathrm{~d}^{3}\right), \mathrm{Mn}^{2+}\left(3 \mathrm{~d}^{5}\right), \mathrm{Fe}^{3+}\left(3 \mathrm{~d}^{5}\right), \mathrm{Co}^{2+}\left(3 \mathrm{~d}^{7}\right)$, or $\mathrm{Ni}^{2+}\left(3 \mathrm{~d}^{8}\right)$ can be considered dilute magnetic semiconductors (DMS)., ${ }^{3,4}$ At higher doping levels, antiferromagnetism and superparamagnetism may coexist due to the formation of dopant clusters.
Furthermore, the size of nanoparticles also influences their magnetic properties. ${ }^{3,4}$

In the case of $\mathrm{Cr}^{3+}$ in a $\mathrm{SnO}_{2}$ matrix, ${ }^{5-9}$ depending on the synthesis route, such as self-combustion, a solubility limit of 2 mol \% is achieved, whereas for samples prepared by the coprecipitation route, followed by annealing at high temperatures, ferromagnetism is observed for $\% \mathrm{Cr}<2.5$, and cluster formation at $\mathrm{Cr}$ concentration $>2.5 \%$ was identified by electron paramagnetic resonance (EPR). EPR experiments have revealed various isolated paramagnetic $\mathrm{Cr}^{3+}$ centers as well as broad signals associated with antiferromagnetic $\mathrm{Cr}^{3+}$-clusters and ferromagnetic resonance lines mainly due to $\mathrm{Cr}^{4+}-\mathrm{Cr}^{3+}$ or $\mathrm{Cr}^{4+}-\mathrm{Cr}^{4+}$ exchange-coupled pairs. On the basis of DFT and the formation energy calculations taking into account a supercell, the presence of two $\mathrm{Cr}^{4+}$ defects in oxygen-rich conditions gives rise to ferromagnetic coupling, whereas the occurrence of $\mathrm{Cr}^{3+}$ pairs associated with oxygen vacancies in oxygen-poor conditions leads to paramagnetic interactions. ${ }^{10}$ To the best of our knowledge, the occurrence of ferromagnetic coupling in Cr-doped cassiterite ${ }^{11-14}$ can only be explained by the presence of $\mathrm{Cr}^{4+}$ or electrons trapped in the lattice due to 
oxygen defects, in interaction with other paramagnetic centers such as $\mathrm{Cr}^{3+}$ or $\mathrm{Cr}^{4+}{ }^{15-18}$ The low solubility of $\mathrm{Cr}^{3+}$ may be related to its lower ionic size ( $0.62 \AA$ in an octahedral site) compared to that of $\mathrm{Sn}^{4+}(0.69 \AA)$, generating a more ionic bond and inducing oxygen defects into the rutile lattice, with octahedral sites sharing edges or faces, creating constraints.

The $\mathrm{Cr}$ doping of tin dioxide also contributes to tuning of the optical absorption properties, and chrome tin orchid cassiterite of the general formula $\mathrm{Sn}_{1-x} \mathrm{Cr}_{x} \mathrm{O}_{2}$ exhibits a purple hue. ${ }^{11,12,14}$ However, the origin of this color is still unresolved but may be mainly due to the occurrence of $\mathrm{Cr}^{3+} / \mathrm{Cr}^{4+}$ valence states in the $\mathrm{SnO}_{2}$ matrix. In malayaite $\mathrm{CaSnSiO}_{5}$ doped with chromium (about 2\%) as ceramic pigment, which develops deep burgundy to pink shades, optical absorption spectroscopy investigations confirm the occurrence of both $\mathrm{Cr}^{4+}$ and $\mathrm{Cr}^{3+}$ ions substituting for $\mathrm{Sn}^{4+}$ in octahedral sites. ${ }^{11,15,19-24}$ Neutron and $\mathrm{X}$-ray diffraction analyses confirm the low $\mathrm{Cr}$ ion solubility $(<3.5 \mathrm{~mol} \%)$ in pyrochlore $\mathrm{Y}_{2} \mathrm{Sn}_{2} \mathrm{O}_{7}$, and diffuse reflectance spectroscopy reveals the occurrence of $\mathrm{Cr}^{4+}$ in octahedral sites, also substituting for $\mathrm{Sn}^{4+}$ and leading to a magenta color. ${ }^{25} \mathrm{On}$ the basis of the Tanabe-Sugano diagram, the crystal field of a $\mathrm{Cr}^{4+}\left(3 \mathrm{~d}^{2}\right)$ ion stabilized in an octahedral site in malayaite and pyrochlore structures is high and estimated to be around 2.5 $\mathrm{eV}$, with a low Racah parameter $B$ varying between 550 and $650 \mathrm{~cm}^{-1}$ and a deduced nephelauxetic effect $\beta=B / B_{\text {free }}$ around $0.55-0.62$, showing the highly covalent character of the $\mathrm{Cr}^{4+}-\mathrm{O}^{2-}$ bond. X-ray photoelectron spectroscopy analysis of $\mathrm{Cr}$-doped malayaite $\mathrm{CaSnSiO}_{5}-\mathrm{CaTiSiO}_{5}$, perovskite $\mathrm{CaSnO}_{3}-\mathrm{CaTiO}_{3}$, or rutile $\mathrm{SnO}_{2}-\mathrm{TiO}_{2}$ shows that the $\mathrm{Cr}^{3+}$ content increases as $\mathrm{Ti}^{4+}$ ions are substituted for $\mathrm{Sn}^{4+}$ and the color changes from reddish purple to brown. ${ }^{17}$ To the best of our knowledge, despite the lower ionic size of $\mathrm{Ti}^{4+}$ in a 6-fold coordination $(0.61 \AA)$ compared to that of $\mathrm{Sn}^{4+}(0.69 \AA)$, but closer to $\mathrm{Cr}^{3+}(0.62 \AA)$ and a fortiori to $\mathrm{Cr}^{4+}(0.55 \AA)$, a stronger hybridization and covalence in $\mathrm{SnO}_{2}$ involving $5 \mathrm{p}$ orbitals instead of $3 \mathrm{~d}$ orbitals in $\mathrm{TiO}_{2}$ may explain the preferential stabilization of $\mathrm{Cr}^{4+}-\mathrm{O}^{2-}$ covalent bonds in tinbased oxides. This point will be further discussed.

Thus, cassiterite $\mathrm{SnO}_{2}$ is a simple network where chromium induces a purple coloration, but the origin of this hue is still unclear. Moreover, the stabilization of isolated $\mathrm{Cr}^{4+}$ and/or $\mathrm{Cr}^{3+}$ species, as well as the occurrence of chromium clusters creating ferromagnetic or antiferromagnetic interactions in this network and their impact on hue change investigated, must be clarified.

In order to get information about the $\mathrm{Cr}$ valence states as well as the formation of $\mathrm{Cr}$ clusters in cassiterite and to follow their evolution versus the $\mathrm{Cr}$ rate and synthesis conditions, $\mathrm{Sn}_{1-x} \mathrm{Cr}_{x} \mathrm{O}_{2}(x=0,0.005,0.01,0.02,0.05$, and 0.1$)$ complex oxides have been prepared by coprecipitation in a basic medium, and then annealed under $\mathrm{O}_{2}$, air, or $\mathrm{Ar}$ at three different temperatures $\left(800,1000\right.$, and $\left.1200{ }^{\circ} \mathrm{C}\right)$ for various heating durations. From the analysis of X-ray diffractograms, optical absorption, and EPR spectra, the influence of the Crdoping rate and the synthesis conditions on the coloration of cassiterite will then be discussed and related to the distribution of $\mathrm{Cr}$ valence states and the occurrence of $\mathrm{Cr}$ clusters.

\section{EXPERIMENTAL SECTION}

$\mathrm{Sn}_{1-x} \mathrm{Cr}_{x} \mathrm{O}_{2}$ complex oxides have been prepared starting from chloride precursors $\mathrm{CrCl}_{3} \cdot 6 \mathrm{H}_{2} \mathrm{O}$ (Aldrich) and $\mathrm{SnCl}_{2} \cdot 5 \mathrm{H}_{2} \mathrm{O}$ (Aldrich, 98\%), coprecipitated in a basic medium $(\mathrm{pH}=10)$, and maturated at room temperature for $1 \mathrm{~h}$. The chromium amount $x$ is between $x=0$ and $x$
$=0.10$ as the solubility limit is reached. Precipitates were washed three times with water and dried in an oven at $T=80^{\circ} \mathrm{C}$ under air for one night. All these oxides were annealed under pure oxygen at different temperatures, 800 and $1000{ }^{\circ} \mathrm{C}$, for 48 and $4 \mathrm{~h}$, respectively. In order to follow the $\mathrm{Cr}$ valence state in $2 \% \mathrm{Cr}-\mathrm{SnO}_{2}$, the material was annealed under pure $\mathrm{Ar}$ at $1000{ }^{\circ} \mathrm{C}$ for $4 \mathrm{~h}$. The pure phases crystallize with the rutile tetragonal type structure (space group (SG): $\mathrm{P4}_{2} / \mathrm{mnm}$ ).

Powder X-ray diffraction patterns have been collected on a Philips X'Pert MPD X-ray diffractometer with Bragg-Brentano geometry, using $\mathrm{K} \alpha 1 / \mathrm{K} \alpha 2$ radiations $\left(8^{\circ}<2 \theta<80^{\circ}\right.$ step of $0.017^{\circ}$ and counting time of $60 \mathrm{~s}$ ). Diffractograms have been refined using the full pattern profile matching method, with a Fullprof software package and conventional reliability factors $\left(R_{\mathrm{p}}\right.$ and $\left.R_{\mathrm{wp}}\right)$. For the diffraction peak profiles, a full width at half maximum $\left(H^{2}\right)$ has been refined with a Pearson VII function, and the estimation of $H^{2}$ determines the crystallite size by applying the Sherrer equation. No instrumental function and Lorentzian or Gaussian shapes for strains have been considered in these refinements. The unit cell and all the diffraction patterns have been indexed on the basis of rutile-type structures (SG: $\left.\mathrm{P}_{2} / \mathrm{mnm}\right)$.

The morphology of $\mathrm{Sn}_{1-x} \mathrm{Cr}_{x} \mathrm{O}_{2}$ nanoparticles was evaluated by high resolution transmission electronic microscopy (HRTEM). HRTEM was performed on a TEM Jeol 2200FS operated at 200 $\mathrm{kV}$ with a field emission gun. The theoretical resolution (fwhm) was nominally $1.9 \AA$, and energy dispersive X-ray spectroscopy (EDX) was used to control the $\mathrm{Sn} / \mathrm{Cr}$ distribution in nanoparticles.

The UV-vis-NIR diffuse reflectance spectra $R(\lambda)$, presented here after a Kubelka-Munk transformation, $K / S=(1-R)^{2} / 2 R$, were recorded at room temperature from 200 to $2500 \mathrm{~nm}$, with a step of 1 $\mathrm{nm}$ and a band length of $2 \mathrm{~nm}$ on a Cary 17 spectrophotometer, using an integration sphere. Halon polymer was used as a white reference for the blank. A mathematic treatment of the obtained spectra allowed the determination of the $L^{*} a^{*} b^{*}$ space parameters (where $L^{*}$ is the luminosity, $a^{*}$ is the green-to-red axis coefficient, and $b^{*}$ is the blueto-yellow axis coefficient). The first step of the treatment consists of obtaining the XYZ tristimulus values (defined by the CIE in 1964) from the integration (on the visible range, i.e., from $\lambda=380 \mathrm{~nm}$ to $800 \mathrm{~nm}$ ) of the product of $x(\lambda), y(\lambda)$, or $z(\lambda)$ functions (CIE, 1964), with the diffuse reflectance spectra function: $X=\int x(\lambda) R(\lambda) \mathrm{d} \lambda$. Then, the transfer equations defined by the CIE, 1976 from XYZ space to the $L^{*} a^{*} b^{*}$ space were used in order to obtain the $L^{*} a^{*} b^{*}$ chromatic parameters. Diffuse reflectance spectra were also fitted considering the arctangent function for the band gap and the Gaussian curves for the $\mathrm{d}-\mathrm{d}\left(\mathrm{Cr}^{4+} / \mathrm{Cr}^{3+}\right)$ electronic transitions. On the basis of a Tauc plot for direct transition with the following equation, $(\alpha h \nu)^{2}=$ A $(h \nu-\mathrm{Eg})$, the $\mathrm{Eg} \mathrm{BG}$ can be estimated for pure $\mathrm{SnO}_{2}$ thermally treated at 800 or $1200{ }^{\circ} \mathrm{C}$.

Electron paramagnetic resonance (EPR) spectra were recorded from room temperature down to $77 \mathrm{~K}$ using a Bruker ESP300E spectrometer operating at an X-band frequency $(9.45 \mathrm{GHz})$ and equipped with a liquid nitrogen dewar. For the presented spectra, the main spectroscopic parameters are microwave power $10 \mathrm{~mW}$, spectral resolution $0.6 \mathrm{mT} / \mathrm{pt}$, and magnetic field modulation frequency 100 $\mathrm{kHz}$ and amplitude $1 \mathrm{mT}$. DPPH was used as an external reference to calibrate the spectrometer. For the estimation of isolated paramagnetic $\mathrm{Cr}^{3+}$ ion concentration, the $\mathrm{Fe}^{3+}$ impurity signal as well as the large resonance line centered at $g \sim 2$ and associated with $\mathrm{Cr}$ clusters were first subtracted from the experimental spectra. The value obtained by the double-integration of the remaining first-derivative curve was then compared to the one calculated from the EPR spectra of the reference compound $\left(\mathrm{KAl}\left(\mathrm{SO}_{4}\right)_{2}\right)$ doped with known amounts of $\mathrm{Cr}^{3+}$ ions.

\section{RESULTS AND DISCUSSION}

3.1. XRD and TEM Analysis. The $\mathrm{Sn}_{1-x} \mathrm{Cr}_{x} \mathrm{O}_{2}$ complex oxides, where $x$ represents the chromium rate, were prepared from the coprecipitation route under a basic medium, followed by annealing under an oxygen atmosphere at $800{ }^{\circ} \mathrm{C}$ for $48 \mathrm{~h}$ 

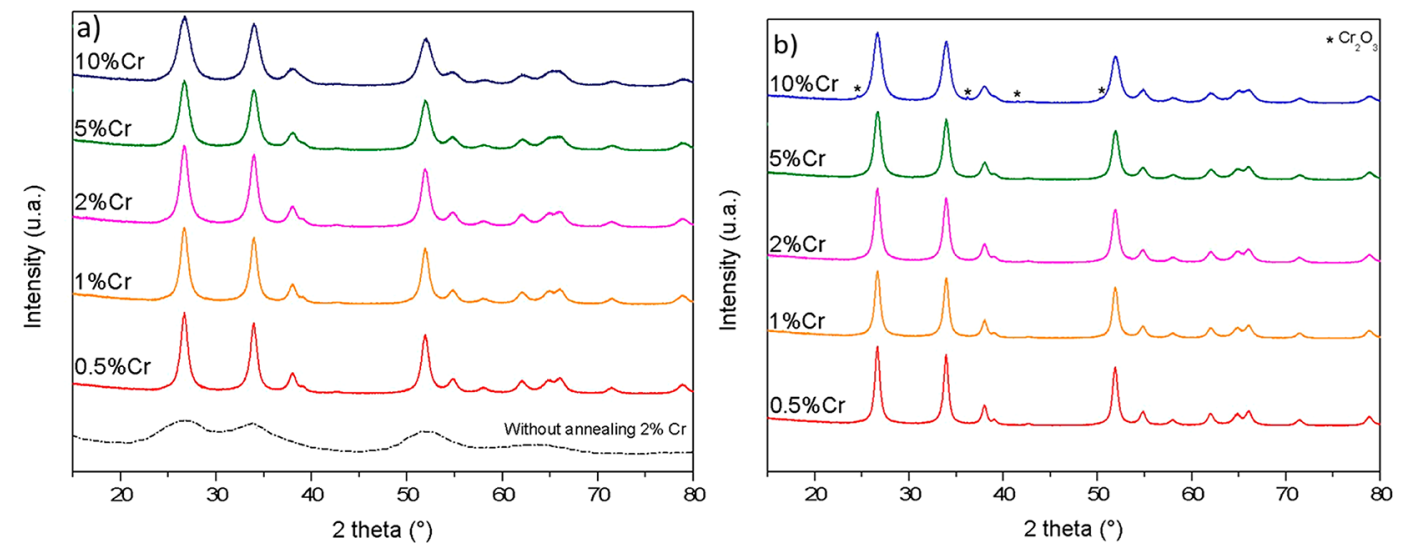

Figure 1. XRD patterns of $\mathrm{Sn}_{1-x} \mathrm{Cr}_{x} \mathrm{O}_{2}$ compounds (with $x=0.005,0.01,0.02,0.05$, and 0.1 ) prepared from the coprecipitation route, followed by postannealing at $800{ }^{\circ} \mathrm{C}, 48 \mathrm{~h}$ (part a) and $1000{ }^{\circ} \mathrm{C}, 4 \mathrm{~h}$ (part b). $\mathrm{Cr}_{2} \mathrm{O}_{3}(*)$ second phase is identified. XRD pattern of $x=0.02$ sample before annealing is also represented in part a.

and at $1000{ }^{\circ} \mathrm{C}$ for $4 \mathrm{~h}$. One should notice that the main diffraction lines corresponding to the rutile structure are already identified on the phase obtained just after precipitation and before annealing. The X-ray diffraction patterns of the asprepared powders are reported in Figure 1. A single rutile $\left(P 4_{2} / \mathrm{mnm}\right.$ space group) phase is identified for all samples annealed at $800{ }^{\circ} \mathrm{C}$ (Figure 1a) and for an $x$ value inferior or equal to $5 \mathrm{~mol} \%$ of chromium for powders annealed at 1000 ${ }^{\circ} \mathrm{C}$ (Figure $1 \mathrm{~b}$ ). For an $x=0.10$ sample annealed at $T=1000$ ${ }^{\circ} \mathrm{C}$, the second phase corresponds to $\mathrm{Cr}_{2} \mathrm{O}_{3}$, and this powder will be not considered further in this study. The solubility limit of chromium in $\mathrm{SnO}_{2}$ is reached between 0.05 and 0.10 for the samples annealed at $T=1000{ }^{\circ} \mathrm{C}$, and it is over $5 \mathrm{~mol} \%$ for the oxides annealed at $T=800{ }^{\circ} \mathrm{C}$. The unit-cell parameters and the crystallite size deduced from full pattern profile matching have been reported in Table 1 , and the unit cell

Table 1. Unit-Cell Parameters and Crystallite Size of $\mathrm{SnO}_{2}$ Compounds $^{a}$

$\begin{array}{cccccc}\begin{array}{c}\text { thermal } \\ \text { treatment }\end{array} & \% \mathrm{Cr} & a(\AA) & c(\AA) & c / a & \begin{array}{c}\text { crystallite } \\ \text { size (nm) }\end{array} \\ 800{ }^{\circ} \mathrm{C}, 48 \mathrm{~h} & 0 & 4.7373(6) & 3.1884(6) & 0.672 & 8(1) \\ & 0.5 & 4.7357(7) & 3.1846(7) & 0.672 & 8(1) \\ & 1 & 4.7353(6) & 3.1852(6) & 0.673 & 8(1) \\ & 2 & 4.7341(7) & 3.1848(7) & 0.673 & 7(1) \\ 1000{ }^{\circ} \mathrm{C}, 4 \mathrm{~h} & 5 & 4.7338(8) & 3.1846(7) & 0.673 & 6(1) \\ & 0 & 4.7364(3) & 3.1866(2) & 0.673 & 13(1) \\ & 0.5 & 4.7355(4) & 3.1852(4) & 0.673 & 11(1) \\ & 1 & 4.7358(4) & 3.1851(4) & 0.673 & 10(1) \\ & 2 & 4.7358(5) & 3.1851(5) & 0.673 & 9(1) \\ & 5 & 4.7361(5) & 3.1849(5) & 0.672 & 9(1)\end{array}$

${ }^{a}$ Undoped and $\mathrm{Cr}$-doped with different molar $\mathrm{Cr}$ concentrations, annealed at $800{ }^{\circ} \mathrm{C}$ for $48 \mathrm{~h}$ and at $1000{ }^{\circ} \mathrm{C}$ for $4 \mathrm{~h}$ under $\mathrm{O}_{2}$.

volume evolution versus $x$ chromium rate is plotted in Figure 2. An example of a full pattern matching of diffractogram of $\mathrm{Sn}_{0.95} \mathrm{Cr}_{0.05} \mathrm{O}_{2}$ composition annealed at $800{ }^{\circ} \mathrm{C}$ under $\mathrm{O}_{2}$ for 48 $\mathrm{h}$ is proposed on Figure $\mathrm{S} 1$. In a cassiterite $\mathrm{SnO}_{2}$ network, the $c / a$ ratio related to the octahedron distortion is around $0.673(1)$, which is superior to 0.645 for $\mathrm{TiO}_{2}\left(0.659\right.$ for $\mathrm{CrO}_{2}$ and 0.653 for $\left.\mathrm{MnO}_{2}\right)^{26-28}$ and also larger than the ideal value $0.586(2-\sqrt{2})$, corresponding to a perfect octahedral site. Even if the six $\mathrm{Sn}-\mathrm{O}$ bond distances are almost equal around $2.055 \AA$, the $\mathrm{SnO}_{6}$ octahedron is more distorted along the 3-

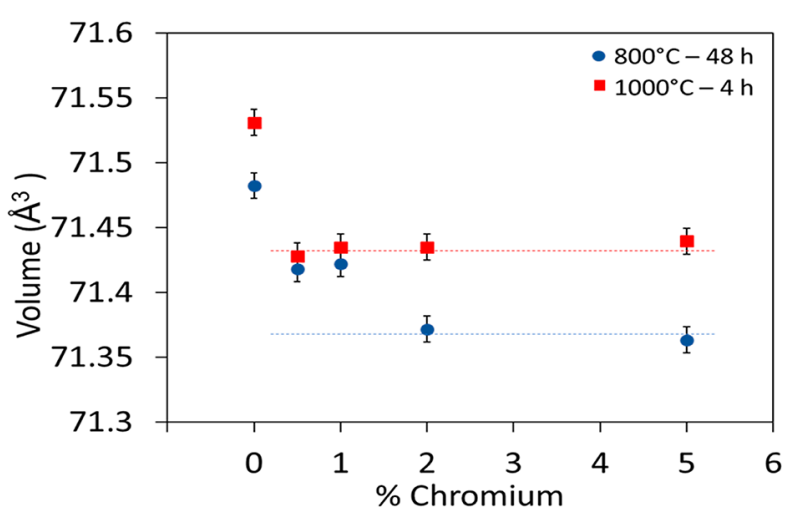

Figure 2. Variation of the unit-cell volume versus $x$ chromium content in $\mathrm{Sn}_{1-x} \mathrm{Cr}_{x} \mathrm{O}_{2}$ oxides with various thermal treatments under $\mathrm{O}_{2}$ (red squares, $800{ }^{\circ} \mathrm{C}, 48 \mathrm{~h}$ and blue dots, $1000{ }^{\circ} \mathrm{C}, 4 \mathrm{~h}$ ).

fold axis than the $\mathrm{TiO}_{6}$ polyhedron. Whatever the $x$ concentration, the $c / a$ ratio remains identical and equal to 0.673 . However, the $\mathrm{Cr}^{4+}\left(\mathrm{t}_{2}{ }^{2}\right)$ ion can be considered as a second-order Jahn-Teller (SOJT) ion stabilized in distorted octahedral sites, whereas the $\mathrm{Cr}^{3+}\left(\mathrm{t}_{2}{ }^{3}\right)$ ion gives rise to an isotropic or slightly distorted octahedron. Thus, concerning the octahedron distortion, there is specific competition between $\mathrm{Cr}^{4+}$ and $\mathrm{Cr}^{3+}$ cations. Because of the lowest ionic size of $\mathrm{Cr}^{3+} / \mathrm{Cr}^{4+}(0.62 / 0.55 \AA$ in 6-fold coordination vs $0.69 \AA$ for $\mathrm{Sn}^{4+}$ ), a decrease of both $a$ unit-cell parameter and volume is expected. However, the presence of oxygen defects associated with the $\mathrm{Cr}^{3+}$ aliovalent doping leads to a decrease of the Madelung energy and an expansion of the unit cell. Thus, a competition can take place between the incorporation of dopants with a lower ionic size and the creation of oxygen defects, which contribute to enlarge the rutile network. The largest decreases of the $a$ unit-cell parameter and volume are observed for samples annealed at $T=800{ }^{\circ} \mathrm{C}$. One should mention that the $c$ parameter changes abruptly for the lowest $\mathrm{Cr}$ content $(0.5 \mathrm{~mol} \%)$ and then remains constant no matter the $\mathrm{Cr}$ rate. Between 2 and $5 \%$ of $\mathrm{Cr}$, the unit-cell parameters are constant and tend to show the formation of $\mathrm{Cr}$ clusters. Concerning the samples annealed at $1000{ }^{\circ} \mathrm{C}$, the unit-cell parameters and the volume seem almost identical no matter the chromium-doping rate. For both these annealing temperatures, the higher the chromium content is, the lower the crystallite size (extracted from Rietveld refinement) is in a first 

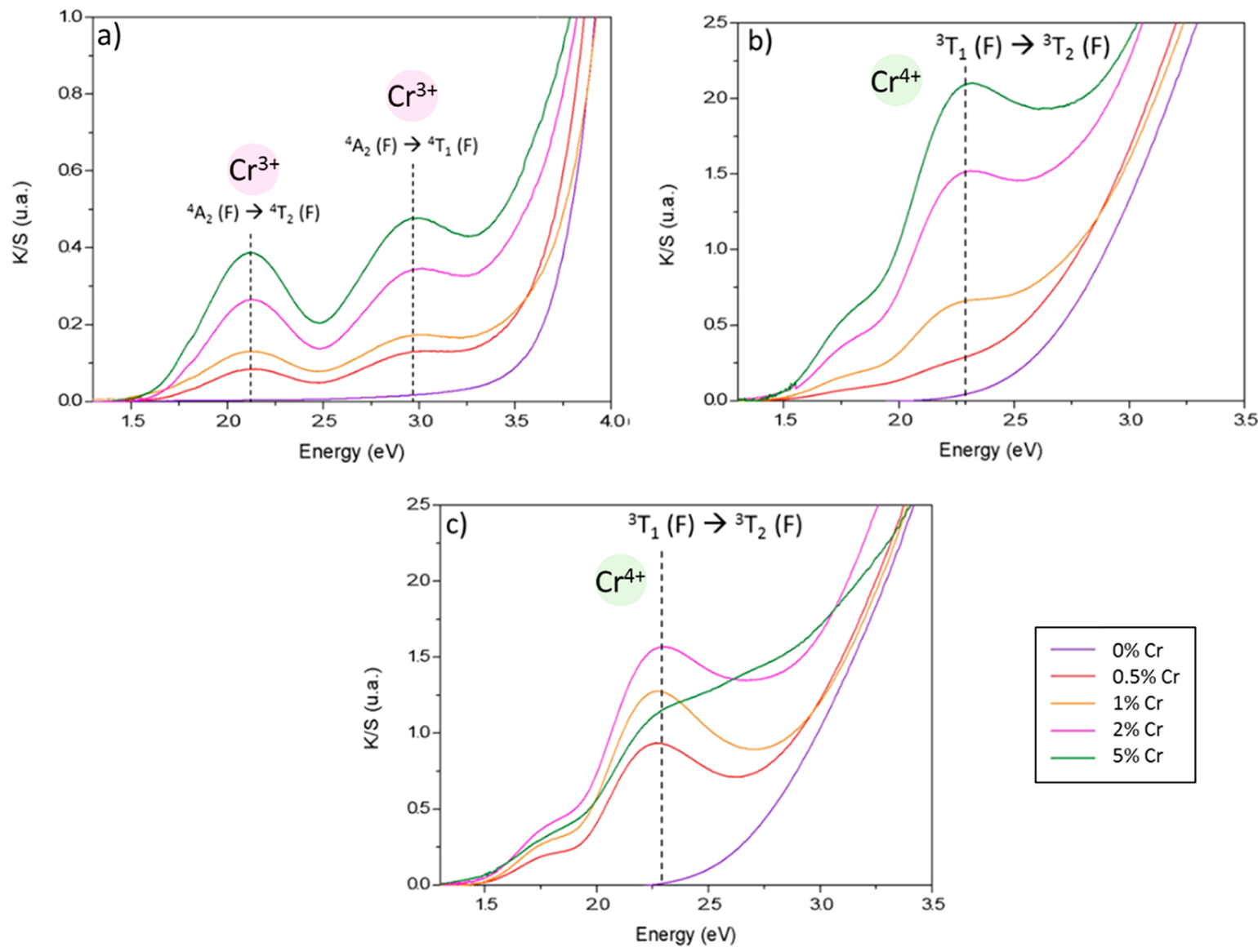

Figure 3. $\mathrm{K} / \mathrm{S}$ optical absorption spectra of $\mathrm{Sn}_{1-x} \mathrm{Cr}_{x} \mathrm{O}_{2}$ compounds (with $x=0.005,0.01,0.02$, and 0.05), just after coprecipitation (part a), annealed at $800{ }^{\circ} \mathrm{C}, 48 \mathrm{~h}$ (part b) and at $1000{ }^{\circ} \mathrm{C}, 4 \mathrm{~h}$ (part c) under $\mathrm{O}_{2}$. The $\mathrm{d}-\mathrm{d}$ transitions corresponding to $\mathrm{Cr}^{3+}$ and $\mathrm{Cr}^{++}$in the octahedral site are labeled in both these figures.
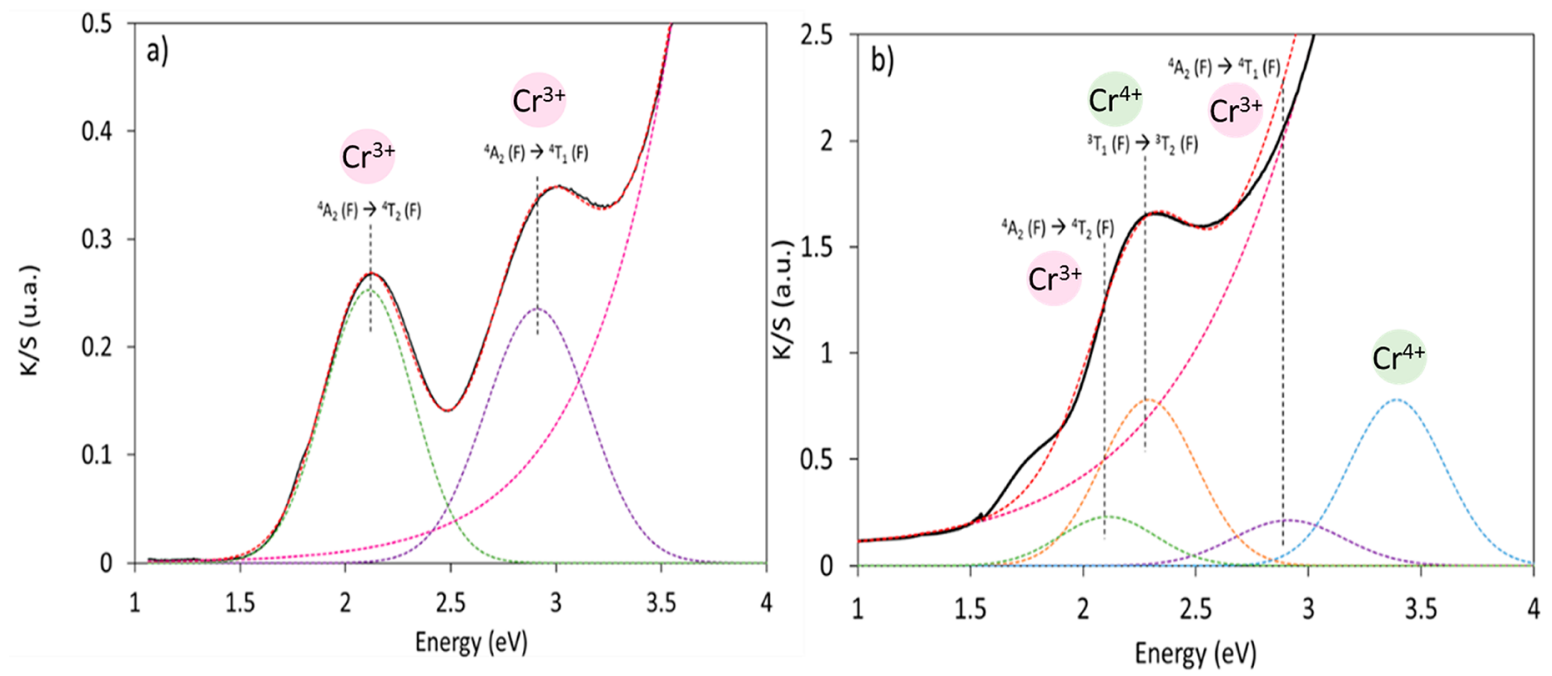

Figure 4. Deconvolution of $K / S$ absorption spectra with only allowed transitions (Laporte selection rules) for $\mathrm{Sn}_{0.98} \mathrm{Cr}_{0.02} \mathrm{O}_{2}$ compound before annealing (part a) and after a thermal treatment at $800{ }^{\circ} \mathrm{C}$ for $48 \mathrm{~h}$ (part b).

approximation considering the error bars. The phases with the highest $\mathrm{Cr}$ content exhibit the smallest crystallites. In order to explain the $\mathrm{Cr}$ effect on the crystallite sizes, one should consider a partial $\mathrm{Cr}$ segregation at the particles surface. The stabilization of the unit-cell parameters is correlated to this segregation and/or to the oxygen defects associated with $\mathrm{Cr}^{3+}$ ions. The unit-cell volume (Figure 2) remains constant starting from $0.5 \% \mathrm{Cr}$ for samples annealed at $\mathrm{T}=1000{ }^{\circ} \mathrm{C}$ and $2 \% \mathrm{Cr}$ for oxides calcined at $T=800{ }^{\circ} \mathrm{C}$. Such an evolution is related to more reducing conditions at $T=1000{ }^{\circ} \mathrm{C}$ (higher $\mathrm{Cr}^{3+}$ content and associated defects) and to a faster segregation phenomena, leading to $\mathrm{Cr}$ clusters due to crystal growing.

TEM micrographs of $x=0.01$ composition are depicted in Figure S2 versus the thermal treatment. Powders obtained just 
after coprecipitation and drying are monodispersed in size and in shape. The crystallite size varies between 2 and $5 \mathrm{~nm}$ (Figure S2a,d). Micrographs on the powders annealed at 800 ${ }^{\circ} \mathrm{C}$ for $48 \mathrm{~h}$ (Figure S2b,e) reveal a slight increase of the grain size, which is between 5 and $25 \mathrm{~nm}$. ( hkl) crystallographic planes of the rutile phase (Figure S2b) are well detected, and EDX analyses show the rather high homogeneity between chromium and tin (Figure S2g). The one annealed at $1000{ }^{\circ} \mathrm{C}$ for $4 \mathrm{~h}$ exhibits larger aggregates around $70 \mathrm{~nm}$ (Figure S2c,f).

3.2. Optical Absorption Analysis. The optical absorption spectra of $\mathrm{Sn}_{1-x} \mathrm{Cr}_{x} \mathrm{O}_{2}$ compounds obtained after coprecipitation in a basic medium and annealed at $T=800{ }^{\circ} \mathrm{C}(48 \mathrm{~h})$ or $T=1000{ }^{\circ} \mathrm{C}(4 \mathrm{~h})$ under $\mathrm{O}_{2}$ are depicted in Figure $3 \mathrm{a}-\mathrm{c}$. Pictures of powders with $\mathrm{Sn}_{0.95} \mathrm{Cr}_{0.05} \mathrm{O}_{2}$ composition annealed under $\mathrm{O}_{2}$ at $800{ }^{\circ} \mathrm{C}$ for $48 \mathrm{~h}$ and $1000{ }^{\circ} \mathrm{C}$ for $4 \mathrm{~h}$ are represented in Figure S3. Clear differences appear between the as-precipitated and the postannealed samples. Two Gaussian peaks around $2.1 \mathrm{eV}(590 \mathrm{~nm})$ and $2.9 \mathrm{eV}(427 \mathrm{~nm})$ in the visible region with almost the same magnitude are identified for oxides before annealing, whereas one major Gaussian function centered at $2.3 \mathrm{eV}(539 \mathrm{~nm})$ is detected for Cr-based cassiterite calcined at high temperatures. The spectrum of the $x$ $=0.02$ compound obtained just after coprecipitation was deconvoluted into two bands with a Gaussian shape associated with $\mathrm{d}-\mathrm{d}$ transitions of $\mathrm{Cr}^{3+}\left(3 \mathrm{~d}^{3}\right)$ in an octahedral coordination and a charge transfer band (CTB) at higher energies $(\arctan (h \nu)$ function) (Figure 4a). On the basis of the Tanabe-Sugano diagram ${ }^{29-32}$ ( $\mathrm{d}^{3}$ electronic configuration), the two bands correspond to the $\mathrm{d}-\mathrm{d}$ transitions ${ }^{4} \mathrm{~A}_{2}(\mathrm{~F}) \rightarrow$ ${ }^{4} \mathrm{~T}_{2}(\mathrm{~F})$ at $2.1 \mathrm{eV}(585 \mathrm{~nm})$ and ${ }^{4} \mathrm{~A}_{2}(\mathrm{~F}) \rightarrow{ }^{4} \mathrm{~T}_{1}(\mathrm{~F})$ at $421 \mathrm{~nm}$. The crystal field splitting and the $B$ Racah parameter were thus estimated around $2 \mathrm{eV}$ and $680 \mathrm{~cm}^{-1}$, respectively, in good agreement with the literature. ${ }^{20}$ These energetic features are reported in Table 2.

Table 2. B Racah Parameters and $10 D q$ Crystal Field Splitting Associated to $\mathrm{Cr}^{4+}$ and $\mathrm{Cr}^{3+}$ in Cr-Doped $\mathrm{SnO}_{2}{ }^{a}$

\begin{tabular}{lllll} 
ion & $\begin{array}{c}B \\
\left(\mathrm{~cm}^{-1}\right)\end{array}$ & $\begin{array}{c}10 D q(\mathrm{eV}) \\
\left(\mathrm{cm}^{-1}\right)\end{array}$ & \multicolumn{1}{c}{$E_{1}(\mathrm{eV} / \mathrm{nm})$} & \multicolumn{1}{c}{$E_{2}(\mathrm{eV} / \mathrm{nm})$} \\
$\mathrm{Cr}^{3+}$ & 680 & 1.98 & ${ }^{4} \mathrm{~A}_{2}(\mathrm{~F}) \rightarrow{ }^{4} \mathrm{~T}_{2}(\mathrm{~F})$ & ${ }^{4} \mathrm{~A}_{2}(\mathrm{~F}) \rightarrow{ }^{4} \mathrm{~T}_{1}(\mathrm{~F})$ \\
& & 15980 & $2.12 / 585$ & $2.94 / 421$ \\
$\mathrm{Cr}^{4+}$ & 650 & 2.4 & ${ }^{3} \mathrm{~T}_{1}(\mathrm{~F}) \rightarrow{ }^{3} \mathrm{~T}_{2}(\mathrm{~F})$ & ${ }^{3} \mathrm{~T}_{1}(\mathrm{~F}) \rightarrow{ }^{3} \mathrm{~T}_{1}(\mathrm{P})$ \\
& & 19470 & $2.29 / 540$ & $3.38 / 366$
\end{tabular}

${ }^{a}$ The two $\mathrm{d}-\mathrm{d}$ transitions energies are also reported.

After it was annealed, the intense band centered at $540 \mathrm{~nm}$ $(2.3 \mathrm{eV})$ was attributed to a ${ }^{3} \mathrm{~T}_{1}(\mathrm{~F}) \rightarrow{ }^{3} \mathrm{~T}_{2}(\mathrm{~F})$ transition associated with $\mathrm{Cr}^{4+}$. Taking into account the Tanabe-Sugano diagram for $\mathrm{d}^{2}$ electronic configuration and a $B$ Racah parameter of $650 \mathrm{~cm}^{-1}$ estimated in $\mathrm{Y}_{2} \mathrm{Sn}_{2} \mathrm{O}_{7}-\mathrm{Cr}^{4+}$ pyrochlore phase, ${ }^{25}$ the $10 D q$ crystal field parameter becomes equal to 2.4 $\mathrm{eV}$. With both these energetic parameters $(10 D q$ and $B)$, a second band should appear in the UV range at $3.39 \mathrm{eV}$ (366 $\mathrm{nm})$ and correspond to a ${ }^{3} \mathrm{~T}_{1}(\mathrm{~F}) \rightarrow{ }^{3} \mathrm{~T}_{1}(\mathrm{P})$ transition. The $B$ Racah parameter value is also consistent with that obtained for $\mathrm{Cr}^{3+}\left(680 \mathrm{~cm}^{-1}\right)$ and associated with a more polarizing cation with a higher nephelauxetic effect. The larger $10 D q$ crystal field is in good agreement with the literature ${ }^{19-25}$ but also higher than the $10 D q\left(\mathrm{Cr}^{3+}\right)$ previously estimated value. Nevertheless, a deconvolution is depicted in Figure $4 b$ with the two $d-d$ bands (with the same intensity) of $\mathrm{Cr}^{4+}$, but without excluding the two $\mathrm{d}-\mathrm{d}$ bands related to $\mathrm{Cr}^{3+}$ (the same magnitude for the two $d-d$ bands in the visible range as well as the same energy position identified in Figure $4 \mathrm{a}$ have been considered) and CTB at a higher energy. Thus, it seems that the $d-d$ band intensity related to $\mathrm{Cr}^{3+}$ species remains much lower than the ones related to $\mathrm{Cr}^{4+}$. Furthermore, the local environment of $\left(\mathrm{d}^{2}\right)-\mathrm{Cr}^{4+}$ ions is probably more distorted or more acentric than that of $\left(d^{3}\right)-\mathrm{Cr}^{3+}$. The $\mathrm{t}_{2}{ }^{2}$ electronic configuration of $\mathrm{Cr}^{4+}$ may indeed induce a pseudo-Jahn-Teller effect (SOJT) of the octahedron involving $\mathrm{t}_{2}$ orbitals. However, a small band around $1.6 \mathrm{eV}(775 \mathrm{~nm})$ has not been taken into account in this deconvolution (Figure 4b). This last contribution may be related to the $\mathrm{Cr}^{4+}-\mathrm{Cr}^{3+}$ intervalence band. The intensity of the $\mathrm{d}-\mathrm{d}$ bands related to $\mathrm{Cr}^{3+}$ and $\mathrm{Cr}^{4+}$ increases regularly versus the Cr-doping rate (Figure 3). However, only for the $x$ $=0.05$ sample annealed at $T=1000{ }^{\circ} \mathrm{C}$, the $\mathrm{d}-\mathrm{d}$ band ${ }^{3} \mathrm{~T}_{1}(\mathrm{~F})$ $\rightarrow{ }^{3} \mathrm{~T}_{2}(\mathrm{~F})$ at $2.3 \mathrm{eV}(540 \mathrm{~nm})$, related to $\mathrm{Cr}^{4+}$, strongly drops despite the increase of $\mathrm{Cr}$ content. It is the signature of the decrease of $\mathrm{Cr}^{4+}$ isolated species in favor of $\mathrm{Cr}^{4+}-\mathrm{Cr}^{3+}$ and $\mathrm{Cr}^{3+}-\mathrm{Cr}^{3+}$ interactions in clusters (Figure $4 \mathrm{a}-\mathrm{c}$ ). Various $\mathrm{Cr}^{3+} / \mathrm{Cr}^{4+}$ and charge transfer bands have been identified in the optical absorption spectra of $x=0.02$ samples annealed at $T=1000{ }^{\circ} \mathrm{C}$ for $4 \mathrm{~h}$ under $\mathrm{O}_{2}$, and these bands drastically drop following the last anneal $\left(T=1200{ }^{\circ} \mathrm{C}, 48 \mathrm{~h}\right.$ under air) (Figure 5 ). This partial deconvolution (Figure S4) leads us to consider that the other bands associated with electronic transfer, such as intervalence exchanges into $\mathrm{Cr}$ clusters, have to be taken into account, especially for oxides calcined at $T=1200{ }^{\circ} \mathrm{C}$.

Finally, the comparison of pure and $\mathrm{Cr}$-doped $(x=0.02)$ cassiterite after coprecipitation, annealed at $T=800{ }^{\circ} \mathrm{C}\left(\mathrm{O}_{2}\right.$, $48 \mathrm{~h}), T=1000{ }^{\circ} \mathrm{C}\left(\mathrm{O}_{2}, 4 \mathrm{~h}\right)$, and $\mathrm{T}=1200{ }^{\circ} \mathrm{C}$ (air, $\left.48 \mathrm{~h}\right)$, allows for identifying qualitatively the evolution of $\mathrm{Cr}^{3+} / \mathrm{Cr}^{4+}$ content with thermal treatment (unit-cell parameters and crystallite size deductions from full pattern profile matching have been reported in Table S1). The annealing temperature also has a clear impact on the band gap (Figure 5). After treatment at $T=800{ }^{\circ} \mathrm{C}$ and $T=1000{ }^{\circ} \mathrm{C}$, the contribution at $540 \mathrm{~nm}(2.3 \mathrm{eV})$ related to $\mathrm{Cr}^{4+}$ is high, whereas at $T=1200$ ${ }^{\circ} \mathrm{C}$, the intensity of this band is low and the electronic transfer into clusters dominates. Moreover, Tauc plots $\left(((K / S) h \nu)^{2}=\right.$ $f(h \nu)$ ) considering a direct band gap (Figure S5) give band gap values of about $3.7 \mathrm{eV}$ for pure $\mathrm{SnO}_{2}$ annealed at $T=1200{ }^{\circ} \mathrm{C}$ and $3 \mathrm{eV}$ for $\mathrm{SnO}_{2}$ calcined at $\mathrm{T}=800{ }^{\circ} \mathrm{C}$. Thus, after treatment at $T=800{ }^{\circ} \mathrm{C}$, a large content of defects into the cassiterite network at the surface (because of the small crystallite size around $7 \mathrm{~nm}$ and in approximation of spherical particles, the surface contribution versus bulk is close to $80 \%$ ) contributes to destabilize the valence band and/or stabilize the conduction band and probably to form $\mathrm{Cr}^{4+}$ species in $\mathrm{Cr}$ doped samples. Moreover, the stronger $5 \mathrm{p}^{0} 5 \mathrm{~s}^{0}\left(\mathrm{Sn}^{4+}\right)-2 \mathrm{p}^{6}$ $\left(\mathrm{O}^{2-}\right)$ orbitals, overlapping more than the $3 \mathrm{~d}^{0}\left(\mathrm{Ti}^{4+}\right)-2 \mathrm{p}^{6}$ $\left(\mathrm{O}^{2-}\right)$ ones, give rise to $\mathrm{Cr}^{4+}$ stabilization as compared to the preferentially more ionic $\mathrm{Cr}^{3+}$ stabilization in rutile $\mathrm{TiO}_{2}$. The creation of $\pi$ nonbonding states in the top of the valence band as impurity energy levels should raise the oxidizing power of $\mathrm{SnO}_{2}$ when annealed at $800{ }^{\circ} \mathrm{C}$ (much lower band gap energy around $3 \mathrm{eV}$ ), and it should also contribute to stabilize $\mathrm{Cr}^{4+}$ species. Furthermore, in Figure S6, the comparison of the optical absorption spectra of Cr-doped $\mathrm{SnO}_{2}(x=0.02)$ annealed at $T=1000{ }^{\circ} \mathrm{C}$ under $\mathrm{O}_{2}$ or $\mathrm{Ar}$ (Figure S6) shows a drastic decrease of the intense band at $540 \mathrm{~nm}$, which is attributed to $\mathrm{Cr}^{4+}$ after treatment under $\mathrm{Ar}$ due to the reduction phenomena associated with the powder color changes from magenta $\left(\mathrm{O}_{2}\right)$ to light brown (Ar). 


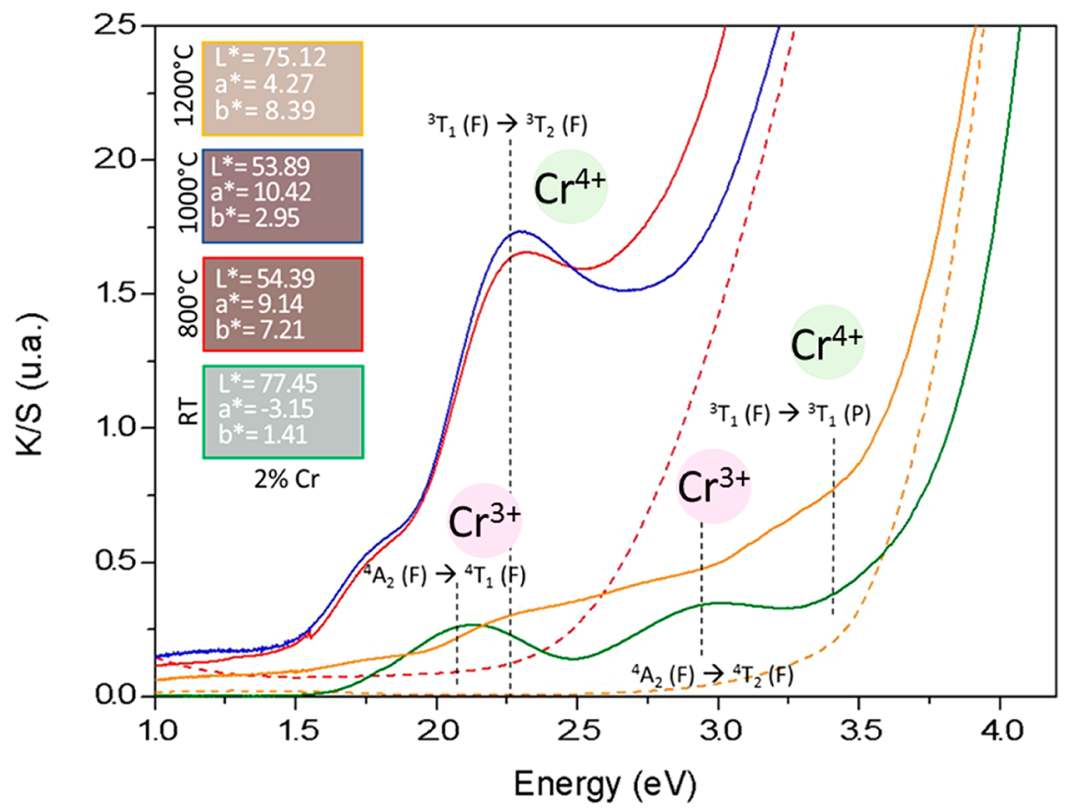

Figure 5. $\mathrm{K} / \mathrm{S}$ absorption spectra of $\mathrm{Sn}_{0.98} \mathrm{Cr}_{0.02} \mathrm{O}_{2}$ (solid line) and $\mathrm{SnO}_{2}$ (dotted line) compounds, at room temperature (green line), that were annealed at 800 and $1000{ }^{\circ} \mathrm{C}$ under oxygen (red and blue lines) and at $1200{ }^{\circ} \mathrm{C}$ under air (yellow lines).

\begin{tabular}{|c|c|c|c|c|c|}
\hline $\begin{array}{l}\text { Powder without } \\
\text { annealing }\end{array}$ & $\begin{aligned} \mathrm{SnO}_{2} \\
\mathrm{~L}^{*}=96.27 \\
\mathrm{a}^{*}=-0.27 \\
b^{*}=3.1\end{aligned}$ & $\begin{aligned} & \mathbf{S n}_{0.995} \mathbf{C r}_{\mathbf{0 . 0 0 5}} \mathbf{O}_{\mathbf{2}} \\
& \mathrm{L}^{*}=85.22 \\
& \mathrm{a}^{*}=-1.91 \\
& b^{*}=2.21\end{aligned}$ & $\begin{array}{l}\mathrm{Sn}_{0.99} \mathrm{Cr}_{0.01} \mathrm{O}_{\mathbf{2}} \\
\mathrm{L}^{*}=83.31 \\
\mathrm{a}^{*}=-2.22 \\
\mathrm{~b}^{*}=1.52\end{array}$ & $\begin{array}{c}\mathrm{Sn}_{0.98} \mathrm{Cr}_{0.02} \mathrm{O}_{2} \\
\mathrm{~L}^{*}=77.45 \\
\mathrm{a}^{*}=3.15 \\
\mathrm{~b}^{*}=1.41\end{array}$ & $\begin{array}{l}\mathrm{Sn}_{0.95} \mathrm{Cr}_{0.05} \mathrm{O}_{2} \\
\mathrm{~L}^{*}=73.62 \\
\mathrm{a}^{*}=3.92 \\
\mathrm{~b}^{*}=1.37\end{array}$ \\
\hline $800^{\circ} \mathrm{C}-48 \mathrm{~h}$ & $\begin{array}{l}L^{*}=81.90 \\
a^{*}=-1.85 \\
b^{*}=27.79\end{array}$ & $\begin{array}{l}L^{*}=75.10 \\
a^{*}=3.03 \\
b^{*}=24.21\end{array}$ & $\begin{array}{l}L^{*}=66.08 \\
a^{*}=6.56 \\
b^{*}=12.73\end{array}$ & $\begin{array}{l}L^{*}=54.39 \\
a^{*}=9.14 \\
b^{*}=7.21\end{array}$ & $\begin{array}{l}L^{*}=47.91 \\
a^{*}=8.73 \\
b^{*}=3.87\end{array}$ \\
\hline $1000^{\circ} \mathrm{C}-4 \mathrm{~h}$ & $\begin{array}{l}L^{*}=78.16 \\
a^{*}=-2.54 \\
b^{*}=19.91\end{array}$ & $\begin{array}{l}L^{*}=62.92 \\
a^{*}=10.78 \\
b^{*}=2.76\end{array}$ & $\begin{array}{l}L^{*}=58.17 \\
a^{*}=11.86 \\
b^{*}=-0.47\end{array}$ & $\begin{array}{l}L^{*}=53.89 \\
a^{*}=10.42 \\
b^{*}=2.95\end{array}$ & $\begin{array}{l}L^{*}=54.58 \\
a^{* *}=6.61 \\
b^{*}=8.15\end{array}$ \\
\hline
\end{tabular}

Figure 6. $L^{*} a^{*} b^{*}$ experimental color parameters of each compound extracted from the $K / S$ optical absorption spectra.
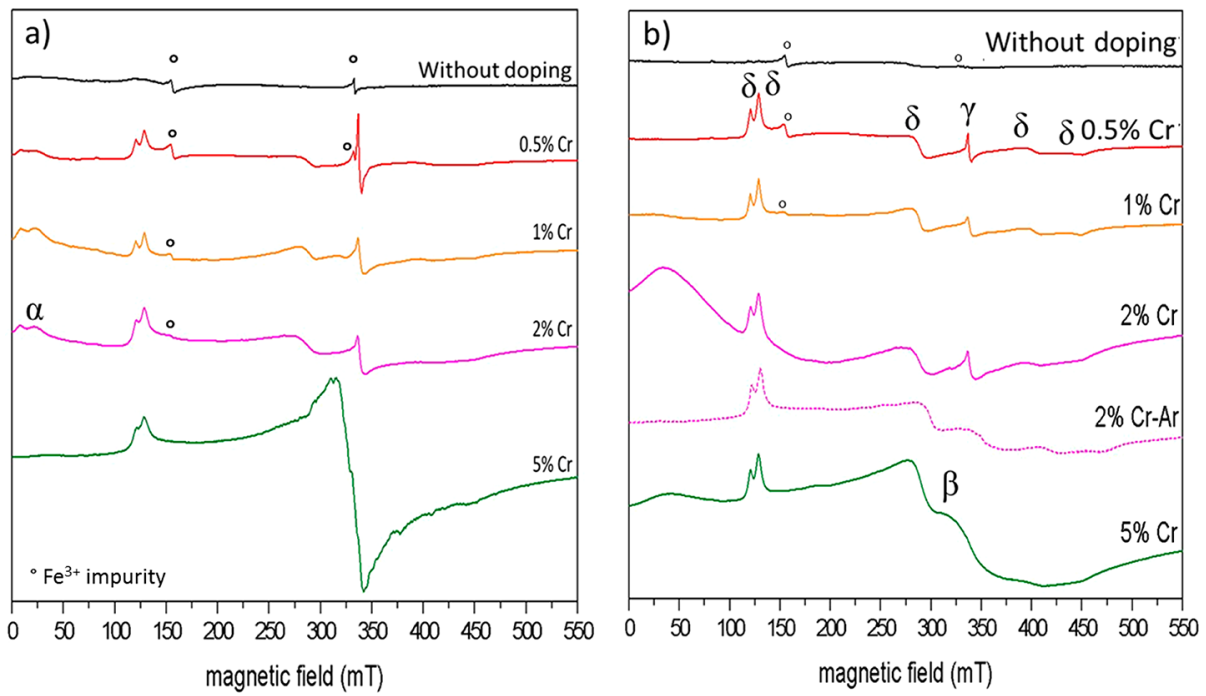

Figure 7. Room temperature X-band EPR spectra of $\mathrm{Sn}_{1-x} \mathrm{Cr}_{x} \mathrm{O}_{2}$ oxides annealed under oxygen at $800{ }^{\circ} \mathrm{C}, 48 \mathrm{~h}$ (part a) and at $1000{ }^{\circ} \mathrm{C}, 4 \mathrm{~h}($ part b). ( ${ }^{\circ}$ corresponds to iron(III) impurity.) The different contributions $\left(\beta, \delta\right.$, and $\gamma$, see text) related to $\mathrm{Cr}^{3+}(\delta) / \mathrm{Cr}^{5+}(\gamma)$ isolated species and $\mathrm{Cr}^{3+}$ clusters $(\beta)$ are labeled on this figure.

From UV-vis optical absorption spectra, colorimetric parameters $L^{*} a^{*} b^{*}$ can be calculated and are presented in Figures 5 and 6 . One can observe a green color for powders that were obtained without annealing, which is typical of $\mathrm{Cr}^{3+}$ in an octahedral site, whereas $\mathrm{Cr}^{4+}$ in an octahedral site is associated with a magenta-purple hue. For Cr-doped $\mathrm{SnO}_{2}$ annealed at $T=800{ }^{\circ} \mathrm{C}$, pigments with purple color are obtained with 2 and $5 \mathrm{~mol} \%$ concentration of chromium and are yellow for lower doping. Then, the magenta color is the typical hue for $\mathrm{Cr}^{4+}$ in an octahedral site, whereas brown and 
yellow colors may correspond to other species involving $\mathrm{Cr}$ interactions. Thus, after annealing at $T=800{ }^{\circ} \mathrm{C}$ for $48 \mathrm{~h}$, a low doping rate around $x=0.005$ should be associated with this kind of species. Annealing at $1000{ }^{\circ} \mathrm{C}$ has another impact on the powder color. Indeed, magenta powder is obtained as $\mathrm{SnO}_{2}$ is doped with $0.5-2 \%$ of chromium with a majority of isolated $\mathrm{Cr}^{4+}$ ions, whereas $5 \% \mathrm{Cr}$ doping leads to a brown powder consistent with the presence of $\mathrm{Cr}-\mathrm{Cr}$ interactions, as previously mentioned. It is worth mentioning that, for a low Cr-doping rate $(x=0.005)$, clear differences can be highlighted between calcination at $\mathrm{T}=800{ }^{\circ} \mathrm{C}$, where $\mathrm{Cr}-\mathrm{Cr}$ interactions seem to dominate, and annealing at $T=1000{ }^{\circ} \mathrm{C}$, where the optical absorption spectra provide evidence for $\mathrm{Cr}^{4+}$ species. The formation of $\mathrm{Cr}$ clusters is promoted for low $\mathrm{Cr}$-doping rates and extended annealing at $800{ }^{\circ} \mathrm{C}$ (2 days), whereas isolated $\mathrm{Cr}^{4+}$ species predominate after a short thermal treatment at a higher temperature $\left(T=1000{ }^{\circ} \mathrm{C}\right.$ for $\left.4 \mathrm{~h}\right)$.

3.3. EPR Analysis. Among all the chromium valence states, only the paramagnetic $\mathrm{Cr}^{3+}$ and $\mathrm{Cr}^{5+}$ ions are detectable by EPR. However, the EPR spectra of $\mathrm{Cr}$-doped oxide compounds $\left(\mathrm{TiO}_{2}, \mathrm{Al}_{2} \mathrm{O}_{3}, \mathrm{SiO}_{2}, \mathrm{SnO}_{2}\right)$ exhibit various signals (commonly designated as $\alpha, \beta, \delta$, and $\gamma$ ) in different proportions depending on the $\mathrm{Cr}$-doping level and the chosen synthesis route. $9,33-38$

The room temperature EPR spectra of $\mathrm{Sn}_{1-x} \mathrm{Cr}_{x} \mathrm{O}_{2}$ compounds, with $x=0,0.005,0.01,0.02$, and 0.05 , that were annealed under oxygen at $800{ }^{\circ} \mathrm{C}$ for $48 \mathrm{~h}$ and $1000{ }^{\circ} \mathrm{C}$ for $4 \mathrm{~h}$ are depicted in Figure 7. Spectra were also recorded at $T=77 \mathrm{~K}$ (Figure S7a,b). The various signals associated with the $\mathrm{Cr}$ species are labeled in Figure $7 \mathrm{a}, \mathrm{b}$ and Figure S7a,b. In addition to the Cr-related resonance lines, weak EPR signals are observed at $g_{\text {eff }}=4.29$ and 2.003 due to a low amount of $\mathrm{Fe}^{3+}$ ions, as an impurity.

The signal labeled $\delta$ is characterized by a fine structure with at least five resonance lines $(g=5.53,5.18,2.32,1.66$, and 1.48 ) within the investigated magnetic field range (Figure $7 \mathrm{~b}$ and Figure S7). It is attributed to isolated $\mathrm{Cr}^{3+}$ ions $\left(\mathrm{d}^{3}\right)$ and can be described by a $S=3 / 2$ spin system, with an effective $g$ value of about 1.975 and high values of $D$ and $E$ zero-field splitting parameters, which are related to the local crystal field and the distortion of the $\left[\mathrm{CrO}_{6}\right]$ octahedron. ${ }^{39,40}$ For each $\mathrm{Cr}$ doped tin oxide, the isolated $\mathrm{Cr}^{3+}$ ions concentration was estimated by double integration of the EPR spectrum after the subtraction of all other observed signals. The values reported in Table 3 are indeed slightly underestimated because some weak resonance lines of the $\mathrm{Cr}^{3+}$ EPR signal are expected at a higher magnetic field (i.e., out of the investigated range);

Table 3. Isolated $\mathrm{Cr}^{3+}$ Content versus Cr-Doping Rate and Thermal Treatment (Temperature and Duration) ${ }^{a}$

\begin{tabular}{ccccc} 
thermal treatment & $\% \mathrm{Cr}$ & $\begin{array}{c}N_{\text {spins }} \times \\
10^{19}\end{array}$ & $\begin{array}{c}\mathrm{mol} \% \text { (isolated } \\
\mathrm{Cr}^{3+} \text { ) } \pm 0.02\end{array}$ & $\begin{array}{c}\text { isolated } \mathrm{Cr}^{3+} \text { ] } \\
\text { doping rate }\end{array}$ \\
\hline $800{ }^{\circ} \mathrm{C}, 48 \mathrm{~h}, \mathrm{O}_{2}$ & 0.5 & 1.21 & 0.10 & $20 \%$ \\
& 1 & 1.22 & 0.10 & $10 \%$ \\
& 2 & 5.66 & 0.47 & $24 \%$ \\
$1000{ }^{\circ} \mathrm{C}, 4 \mathrm{~h}, \mathrm{O}_{2}$ & 5 & 4.15 & 0.35 & $7 \%$ \\
& 0.5 & 2.42 & 0.20 & $40 \%$ \\
& 2 & 2.97 & 0.25 & $25 \%$ \\
& 5 & 5.77 & 0.18 & $10 \%$
\end{tabular}

${ }^{a}$ Estimated from EPR spectra recorded at room temperature. nonetheless, they are directly proportional to the real isolated $\mathrm{Cr}^{3+}$ concentrations.

The narrow axial signal, labeled $\gamma$, with $g_{\perp}=1.974$ and $g_{\|}=$ 1.945 is assigned to the $\mathrm{Cr}^{5+}\left(\mathrm{d}^{1}\right)$ paramagnetic species located at the surface of the tin oxides. ${ }^{33}$ After annealing Cr-doped $\mathrm{SnO}_{2}(x=0.02)$ under $\mathrm{Ar}$ at $\mathrm{T}=1000{ }^{\circ} \mathrm{C}$, the intensity of this signal is significantly reduced, confirming the above assignment (Figure $7 b$ ).

The $\beta$ signal $\left(g_{\text {eff }}=1.98\right)$ is usually associated with exchangecoupled or antiferromagnetically coupled $\mathrm{Cr}^{3+}$ ions $(S=3 / 2)$, i.e., $\mathrm{Cr}^{3+}$-clusters of various sizes (two or three units). ${ }^{9,34}$ This broad and symmetric resonance line is especially observed for the compounds with $x=0.05$ annealed at $T=800{ }^{\circ} \mathrm{C}$ or $\mathrm{T}=$ $1000{ }^{\circ} \mathrm{C}$.

Clusters involving ferromagnetic interactions between $\mathrm{Cr}^{4+}$ $\left(t_{2}{ }^{2}\right)$ and $\mathrm{Cr}^{3+}\left(\mathrm{t}_{2}{ }^{3}\right)$ ions are characterized by a broad and intense signal (labeled $\alpha$ in Figure S7). As the temperature decreases, this ferromagnetic resonance line becomes broader and less intense and shifts toward low magnetic fields. Such an evolution was especially observed for the $x=0.02$ compound annealed at $T=1000{ }^{\circ} \mathrm{C}$ under $\mathrm{O}_{2}$ (Figure 7 and Figure S7), attesting to the occurrence of ferromagnetic clusters in this sample in good agreement with the literature illustrated by the magnetic hysteresis loops. ${ }^{4,35-37}$ For samples with Cr-doping rates up to $2 \mathrm{~mol} \%$ that were annealed at $800{ }^{\circ} \mathrm{C}$ under $\mathrm{O}_{2}$, a smaller FM signal associated with $\mathrm{Cr}^{4+}-\mathrm{Cr}^{3+}$ interactions is observed at a low magnetic field (Figure 7a) and disappears at $T=77 \mathrm{~K}$ (Figure S7a). Such an RT signal is absent for $x=$ 0.005 and $x=0.01$ compositions annealed at $T=1000{ }^{\circ} \mathrm{C}$, leading us to consider only isolated $\mathrm{Cr}$ species (Figure $7 \mathrm{~b}$ ). As mentioned previously concerning the optical absorption spectra of oxides with a low $\mathrm{Cr}$-rate $(0.5$ and $1 \mathrm{~mol} \% \mathrm{Cr}$ ), $\mathrm{Cr}^{4+}-\mathrm{Cr}^{3+}$ interactions are observed for samples annealed at $T$ $=800{ }^{\circ} \mathrm{C}$, whereas EPR analyses confirm the occurrence of isolated species for these compositions annealed at $T=1000$ ${ }^{\circ} \mathrm{C}$. The absence of this low-field signal for $x=0.02$ composition annealed at $T=1000{ }^{\circ} \mathrm{C}$ under $\mathrm{Ar}$ is clearly the signature (Figure S7b) of the strong decrease of the $\mathrm{Cr}^{4+}$ amount in this sample as well as the broadening of the $\beta$-signal around $g \sim 2$ related to $\mathrm{Cr}^{3+}$ clusters.

For low Cr-doping levels ( 0.5 and $1 \mathrm{~mol} \%)$, the content of isolated $\mathrm{Cr}^{3+}$, reported in Table 3 , is clearly higher for the samples annealed at $T=1000{ }^{\circ} \mathrm{C}$, and fewer exchange-coupled $\mathrm{Cr}^{3+}-\mathrm{Cr}^{4+}$ species are evidenced, which is in good agreement with the optical absorption curves showing a stronger absorption at $540 \mathrm{~nm}(2.3 \mathrm{eV})$, related to the $\mathrm{Cr}^{4+} \mathrm{d}-\mathrm{d}$ transition (Figure 3b,c). For 2 mol \% Cr-doped samples, a higher content of isolated $\mathrm{Cr}^{3+}(24 \%)$ is detected for samples annealed at $\mathrm{T}=800{ }^{\circ} \mathrm{C}$ for $48 \mathrm{~h}$ under $\mathrm{O}_{2}$ compared to the one calcined at $1000{ }^{\circ} \mathrm{C}$ under $\mathrm{O}_{2}$ for $4 \mathrm{~h}$ (only 9\%). In this latter compound, on the basis of EPR spectra recorded at RT and $T=77 \mathrm{~K}$, one should note the occurrence of more ferromagnetic $\mathrm{Cr}^{4+}-\mathrm{Cr}^{3+}$ interactions with a lower content of isolated $\mathrm{Cr}^{3+}$ than in the sample annealed at $T=800{ }^{\circ} \mathrm{C}$. Starting from a $2 \mathrm{~mol} \% \mathrm{Cr}$-doping rate, annealing at $\mathrm{T}=1000$ ${ }^{\circ} \mathrm{C}$ clearly gives rise to an enhancement of $\mathrm{Cr}^{4+}-\mathrm{Cr}^{3+}$ interactions for a $5 \mathrm{~mol} \% \mathrm{Cr}$ concentration. Furthermore, it is worthwhile noting that, as expected, the highest concentration of isolated $\mathrm{Cr}^{3+}$ (almost $1 \mathrm{~mol} \%$ ) was detected for the $\mathrm{Sn}_{0.98} \mathrm{Cr}_{0.02} \mathrm{O}_{2-\delta}$ complex oxide annealed at $\mathrm{T}=1000{ }^{\circ} \mathrm{C}$ for 4 $\mathrm{h}$ under $\mathrm{Ar}$, whereas the same sample that was calcined at $\mathrm{T}=$ $1000{ }^{\circ} \mathrm{C}$ for $4 \mathrm{~h}$ under $\mathrm{O}_{2}$ contains only $0.2 \mathrm{~mol} \%$ of isolated $\mathrm{Cr}^{3+}$ ions (Figure S7). 
A competition between the stabilization of $\mathrm{Cr}^{4+}$ and $\mathrm{Cr}^{3+}$ isolated ions as well as the occurrence of $\mathrm{Cr}^{3+}-\mathrm{Cr}^{3+}$ and $\mathrm{Cr}^{4+}-$ $\mathrm{Cr}^{3+}$ interactions, inducing defects into $\mathrm{SnO}_{2}$ matrix, occurs as a function of annealing temperature and atmosphere. Taking into account the content of isolated $\mathrm{Cr}^{3+}$ (estimated by EPR), isolated $\mathrm{Cr}^{4+}$ (deduced qualitatively from optical absorption), and $\mathrm{Cr}^{3+}-\mathrm{Cr}^{4+}$ interactions (revealed by EPR and optical absorption), the following tendencies can be proposed. A high content of isolated $\mathrm{Cr}^{4+}$ as well as isolated $\mathrm{Cr}^{3+}$ ions can be reached after annealing under $\mathrm{O}_{2}$ at $T=1000{ }^{\circ} \mathrm{C}$ for a very low $\mathrm{Cr}$-doping rate $(0.5$ and $1 \mathrm{~mol} \%)$. With the $\mathrm{Cr}$ concentration increase (up to $5 \mathrm{~mol} \%$ ) or with the annealing temperature increase, the formation of $\mathrm{Cr}-\mathrm{Cr}$ interactions increases. Also the increased annealing temperature has a reductive effect favoring the isolated $\mathrm{Cr}^{3+}$ concentration and $\mathrm{Cr}^{3+}-\mathrm{Cr}^{4+}$ interactions. Then, it is better to anneal coprecipitated samples at $T=800{ }^{\circ} \mathrm{C}$ under $\mathrm{O}_{2}$ for a long time (2 days) with a high $\mathrm{Cr}$ rate (from 2 to $5 \mathrm{~mol} \%$ ) in order to induce a high amount of isolated $\mathrm{Cr}^{4+}$ ions, to reduce the number of defects due to $\mathrm{Cr}^{3+}$ species, and to get a strong purple color. Furthermore, calcination at $T=1000{ }^{\circ} \mathrm{C}$ under $\mathrm{O}_{2}$ with a shorter time (4 $\mathrm{h}$ instead of $48 \mathrm{~h}$ ) allows for reducing the $\mathrm{Cr}$ content ( $\leq 2 \mathrm{~mol}$ $\%)$ to obtain the lighter purple hue associated with a high content of isolated $\mathrm{Cr}^{4+}$ entities. Finally as far as the magnetic interactions are concerned, in the case of the intermediate $\mathrm{Cr}$ concentration ( $2 \mathrm{~mol} \%$ ) with the highest rate of ferromagnetic $\mathrm{Cr}^{3+}-\mathrm{Cr}^{4+}$ interactions for samples annealed at $\mathrm{T}=1000{ }^{\circ} \mathrm{C}$, the isolated $\mathrm{Cr}^{3+}$ content decreases with the annealing temperature, whereas the formation of $\mathrm{Cr}^{3+}-\mathrm{Cr}^{3+}$ interactions is promoted for a larger $\mathrm{Cr}$ rate $(5 \mathrm{~mol} \%)$ along with the reduction of $\mathrm{Cr}^{3+}-\mathrm{Cr}^{4+}$ ferromagnetic interactions.

\section{CONCLUSION}

The study of new inorganic pigments with a pink-magentapurple color scale led us to focus on Cr-doped Sn-based oxides and especially $\mathrm{Sn}$-doped cassiterite. Actually, the hue strongly varies with the $\mathrm{Cr}$ content, and the chromium valence state is related to the calcination temperature under an oxygen flow. The control of the isolated $\mathrm{Cr}^{4+}$-doping rate at the origin of visible absorption band around $540 \mathrm{~nm}$ is tricky because of the occurrence of ferromagnetic $\mathrm{Cr}^{4+}-\mathrm{Cr}^{3+}$ interactions and cluster formation as well as the more reduced isolated $\mathrm{Cr}^{3+}$ species. Furthermore, the intensity of this peculiar band and the shape of the UV-vis absorption spectra are strongly dependent on the $\mathrm{Cr}$-doping rate as well as the temperature of the thermal treatment under an $\mathrm{O}_{2}$ atmosphere, related to $\mathrm{Cr}$ valence states and $\mathrm{Cr}$ cluster stabilization. In order to go further into detail, an accurate EPR analysis has been carried out with the estimation of isolated $\mathrm{Cr}^{3+}$-doping rate versus the total Cr-doping molar concentration and the annealing temperature. Thus, an optimal amount of ferromagnetic $\mathrm{Cr}^{4+}-\mathrm{Cr}^{3+}$ interactions in $2 \mathrm{~mol} \% \mathrm{Cr}$-doped $\mathrm{SnO}_{2}$ annealed at $\mathrm{T}=1000{ }^{\circ} \mathrm{C}$ under $\mathrm{O}_{2}$ for $4 \mathrm{~h}$ has been evidenced, whereas lower ferromagnetic $\mathrm{Cr}^{4+}-\mathrm{Cr}^{3+}$ interactions appear for the same sample calcined at $T=800{ }^{\circ} \mathrm{C}$ for 2 days, with also a higher rate of isolated $\mathrm{Cr}^{3+}$ ions (approximatively 3 times more than a sample annealed at $\left.\mathrm{T}=1000^{\circ} \mathrm{C}\right) \cdot \mathrm{Cr}^{4+}-\mathrm{Cr}^{3+}$ and $\mathrm{Cr}^{3+}-$ $\mathrm{Cr}^{3+}$ interactions that form into clusters are strongly dependent on the calcination temperature but also on the $\mathrm{Cr}$-doping rate. A higher annealing temperature and a shorter calcination time limit the formation of isolated $\mathrm{Cr}^{3+}$ species and preferentially stabilize the $\mathrm{Cr}^{4+}-\mathrm{Cr}^{3+}$ interactions into clusters. Furthermore, the isolated $\mathrm{Cr}^{3+}$-doping rate decreases gradually versus the total $\mathrm{Cr}$ content for mol $\% \mathrm{Cr} \leq 2 \%$, leading to a strong increase of isolated $\mathrm{Cr}^{4+}$ species and/or $\mathrm{Cr}^{4+}-\mathrm{Cr}^{3+}$ cluster content. This latter key point perfectly illustrates the more covalent character of the $\mathrm{SnO}_{2}$ cassiterite network than that of the rutile $\mathrm{TiO}_{2}$, with the stronger $5 \mathrm{p}(\mathrm{Sn})-2 \mathrm{p}(\mathrm{O})$ orbital overlap and the hybridization stabilizing a high content of highly oxidative $\mathrm{Cr}^{4+}$ species in this network, with a lower band gap around $3 \mathrm{eV}$ and in a first approximation, "oxidative" energy impurity levels (p-type) on the top of the valence band associated with oxygen species.

\section{Supporting Information}

The Supporting Information is available free of charge at https://pubs.acs.org/doi/10.1021/acs.inorgchem.9b02943.

Figures of full pattern profile matching, HRTEM micrographs, pictures of powders, deconvolution of $K /$ $S$ absorption spectra, Tauc plots, $K / S$ optical absorption spectra, and X-band EPR spectra, and tables of unit-cell parameters and crystalline size (PDF)

\section{Corresponding Author}

*E-mail: alain.demourgues@icmcb.cnrs.fr. ORCID

Cyril Brochon: 0000-0003-3242-1574

Alain Demourgues: 0000-0002-3828-8498

\section{Author Contributions}

The manuscript was written through contributions of all authors. All authors have given approval to the final version of the manuscript.

\section{Notes}

The authors declare no competing financial interest.

\section{REFERENCES}

(1) Sukriti; Chand, P. Effect of $\mathrm{pH}$ values on the structural, optical and electrical properties of $\mathrm{SnO} 2$ nanostructures. Optik 2019, 181, $768-778$.

(2) Elango, G.; Kumaran, S. M.; Kumar, S. S.; Muthuraja, S.; Roopan, S. M. Green synthesis of $\mathrm{SnO} 2$ nanoparticles and its photocatalytic activity of phenolsulfonphthalein dye. Spectrochim. Acta, Part A 2015, 145, 176-180.

(3) Urs, K.; Bhat, S. V.; Kamble, V. On exceeding the solubility limit of $\mathrm{Cr}^{+3}$ dopants in $\mathrm{SnO}_{2}$ nanoparticles based dilute magnetic semiconductors. J. Appl. Phys. 2018, 123 (16), 161518.

(4) Andronenko, S. I.; Misra, S. K. A Review of EPR Studies on Magnetization of Nanoparticles of Dilute Magnetic Semiconductors Doped by Transition-Metal Ions. Appl. Magn. Reson. 2015, 46 (6), 693-707.

(5) Matteucci, F.; Cruciani, G.; Dondi, M.; Raimondo, M. The role of counterions ( $\mathrm{Mo}, \mathrm{Nb}, \mathrm{Sb}, \mathrm{W}$ ) in $\mathrm{Cr}$-, $\mathrm{Mn}$-, $\mathrm{Ni}$ - and $\mathrm{V}$-doped rutile ceramic pigments. Ceram. Int. 2006, 32 (4), 385-392.

(6) Castro, R. H. R.; Rufner, J.; Hidalgo, P.; Gouvêa, D.; Coaquira, J. A. H.; Benthem, K. Surface Segregation in Chromium-Doped Nanocrystalline Tin Dioxide Pigments. J. Am. Ceram. Soc. 2012, 95 (1), 170-176.

(7) Zou, J. Low temperature preparation of Cr-doped rutile pigments with good colour properties. Dyes Pigm. 2013, 97 (1), $71-76$.

(8) Hajjaji, W.; Zanelli, C.; Seabra, M. P.; Dondi, M.; Labrincha, J. A. Cr-doped perovskite and rutile pigments derived from industrial by-products. Chem. Eng. J. 2011, 171 (3), 1178-1184. 
(9) Dvoranova, D.; Brezova, V.; Mazur, M.; Malati, M. A. Investigations of metal-doped titanium dioxide photocatalysts. Appl. Catal., B 2002, 37, 91-105.

(10) Kim, R.; et al. Charge and magnetic states of rutile $\mathrm{TiO}_{2}$ doped with Cr ions. J. Phys.: Condens. Matter 2014, 26 (14), 146003.

(11) Lopez-Navarrete, E.; Caballero, A.; Orera, V.; Lázaro, F.; Ocaña, M. Oxidation state and localization of chromium ions in $\mathrm{Cr}$ doped cassiterite and Cr-doped malayaite. Acta Mater. 2003, 51 (8), 2371-2381.

(12) Doménech, A.; Torres, F. J.; Ruiz de Sola, E.; Alarcón, J. Electrochemical Detection of High Oxidation States of Chromium(IV andV) in Chromium-Doped Cassiterite and Tin-Sphene Ceramic Pigmenting Systems. Eur. J. Inorg. Chem. 2006, 2006 (3), 638-648.

(13) Kuppan, M.; et al. Structural and Magnetic Properties of $\mathrm{Cr}$ Doped SnO2 Nanopowders Prepared by Solid State Reaction. Mech. Mater. Sci. Eng. J. 2017, 9.

(14) Tena, M. A.; Meseguer, S.; Gargori, C.; Forés, A.; Badenes, J. A.; Monrós, G. Study of $\mathrm{Cr}-\mathrm{SnO} 2$ ceramic pigment and of $\mathrm{Ti} / \mathrm{Sn}$ ratio on formation and coloration of these materials. J. Eur. Ceram. Soc. 2007, 27 (1), 215-221.

(15) Heyns, A. M.; Harden, P. M. Evidence for the existence of $\mathrm{cr}(\mathrm{IV})$ in chromium-doped malayaite $\mathrm{Cr} 4+\mathrm{CaSnOSiO} 4$ a resonance raman study. J. Phys. Chem. Solids 1999, 60, 277-284.

(16) Tcheichvili, L.; Weyl, W. A. The synthesis of ceramic pigments. Glass Ind. 1963, 44, 234.

(17) Kato, M.; Unuma, H.; Takahashi, M. Color modification of chromium-tin pik pigment by substitution of $\mathrm{Ti}$ for Sn. Nippon Seramikkusu Kyokai Gakujutsu Ronbunshi 2000, 108 (5), 478-481.

(18) Escribano, P.; Guillem, M.; Guillem, C. Study of the SnO2Cr2O3 system. Trans. Faraday Soc. 2017, 82 (6), 208-210.

(19) Costa, G.; Ribeiro, M. J.; Labrincha, J. A.; Dondi, M.; Matteucci, F.; Cruciani, G. Malayaite ceramic pigments prepared with galvanic sludge. Dyes Pigm. 2008, 78 (2), 157-164.

(20) Cruciani, G.; et al. Malayaite ceramic pigments: A combined optical spectroscopy and neutron/X-ray diffraction study. Mater. Res. Bull. 2009, 44 (8), 1778-1785.

(21) Yongvanich, N.; Wangwanich, N.; Phomwana, N. Sol-gel Synthesis and Optical Properties of Malayaite Ceramic Colour Pigments. Sains Malays. 2018, 47 (3), 581-587.

(22) Zhang, L.; Pi, Z.; Yang, C.; Tian, X.; Zhang, S. Synthesis of Chromium-Doped Malayaite Pigments from Wastewater Containing Low Chromium(VI). J. Air Waste Manage. Assoc. 2010, 60 (10), $1257-1261$.

(23) Harisanov, V.; Pavlov, R. S.; Marinova, I. T.; Kozhukharov, V.; Carda, J. B. Influence of crystallinity on chromatic parameters of enamels coloured with malayaite pink pigments. J. Eur. Ceram. Soc. 2003, 23 (3), 429-435.

(24) Tammina, S. K.; Mandal, B. K.; Kadiyala, N. K. Photocatalytic degradation of methylene blue dye by nonconventional synthesized SnO2 nanoparticles. Environ. Nanotechnol. Monit. Manag. 2018, 10, 339-350.

(25) Matteucci, F.; Cruciani, G.; Dondi, M.; Baldi, G.; Barzanti, A. Crystal structural and optical properties of $\mathrm{Cr}$-doped $\mathrm{Y} 2 \mathrm{Ti2O} 7$ and Y2Sn2O7 pyrochlores. Acta Mater. 2007, 55 (7), 2229-2238.

(26) Baur, W. ICSD - 393 - MnO2. Acta Crystallogr., Sect. B: Struct. Crystallogr. Cryst. Chem. 1976, 32, 2200-2204.

(27) Baur, W.; Khan, A. A. ICSD-9161-TiO2. Acta Crystallogr., Sect. B: Struct. Crystallogr. Cryst. Chem. 1971, 27, 2133-2139.

(28) Porta, P.; Marezio, M.; Remeika, J. P.; Dernier, P. D. ICSD9423-CrO2. Mater. Res. Bull. 1972, 7, 157-161.

(29) Tanabe, Y.; Sugano, S. On the absorption spectra of complex ions I. J. Phys. Soc. Jpn. 1954, 9 (5), 753-766.

(30) Tanabe, Y.; Sugano, S. On the absorption spectra of complex ions II. J. Phys. Soc. Jpn. 1954, 9 (5), 766-779.

(31) Tanabe, Y.; Sugano, S. On the absorption spectra of complex ions III. J. Phys. Soc. Jpn. 1956, 11 (8), 864-877.

(32) Tanabe, Y.; Kamimura, H. On the absorption spectra of complex ions IV. J. Phys. Soc. Jpn. 1958, 13 (4), 394-411.
(33) Weckhuysen, B.; Schoonheydt, R.; Mabbs, F.; Collison, D. Electron paramagnetic resonance of heterogeneous chromium catalysts. J. Chem. Soc., Faraday Trans. 1996, 92 (13), 2431-2436.

(34) Harrison, P. G.; Lloyd, N. C.; Daniell, W. The Nature of the Chromium Species Formed during the Thermal Activation of Chromium-Promoted Tin(IV) Oxide Catalysts: An EPR and XPS Study. J. Phys. Chem. B 1998, 102 (52), 10672-10679.

(35) Kohler, K.; Schlapper, C.; Von Zelewsky, A.; Nickl, J.; Engweiler, J.; Baiker, A. Chromia supported titania: An EPR study of the chemical and structural changes occuring during catalyst genesis. J. Catal. 1993, 143, 201-214.

(36) Misra, S. K.; Andronenko, S. I.; Rao, S.; Bhat, S. V.; Van Komen, C.; Punnoose, A. Cr3+ electron paramagnetic resonance study of Sn1-xCrxO2 (0.00 $\leq x \leq 0.10)$. J. Appl. Phys. 2009, 105 (7), $07 \mathrm{C} 514$.

(37) Amorelli, A.; Evans, J. C.; Rowlands, C. C.; Egerton, T. A. An electron spin resonance study of rutile and anatase titanium dioxide polycrystalline powders treated with transition-metal ions. J. Chem. Soc., Faraday Trans. 1 1987, 83 (12), 3541-3548.

(38) Philip, J.; et al. Carrier-controlled ferromagnetism in transparent oxide semiconductors. Nat. Mater. 2006, 5 (4), 298-304.

(39) From, W. H. Electron Paramagnetic Resonance of Cr 3+ in Sn O 2. Phys. Rev. 1963, 131 (3), 961.

(40) Hikita, H.; Takeda, K.; Kimura, Y. EPR of new Cr3+ centers in SnO2 crystals. Phys. Status Solidi A 1990, 119 (1), 251-257. 